\title{
S-6 免疫学的ハイリスク患者の腎移植
}

東京女子医科大学 腎臓病総合医療センター 泌尿器科、第三外科、 新潟大学泌尿器科

田邊一成、石川暢夫、徳本直彦、尊田和徳、高橋公太、古賀祥治 八木沢隆、河合達郎、㴊之上昌平、合谷信行、中沢速和、東間紘 太田和夫

免疫学的ハイリスク患者として、A B O血液型不適合腎移植、二次移 植、前感作抗体陽性例、非血縁者間腎移植などが考えられるが、最近の 免疫抑制療法の進歩によりその成績は通常の腎移植症例と比較しても遜 色のないものとなってきている。A B O血液型不適合腎移植術はドナー 不足を解消し適応の拡大をはかるという面からはきわめて有効な方法で ある。A B O血液型不適合腎移植術では術前の血漿交換が重要な前処置 となっており、これにより自然抗体による超急性拒絶反応が予防でき、 A B O 血液型不適合腎移植術が安全におこなわれる。当施設では現在ま でに約 70 例のABO血液型不適合腎移植術を行ってきたが、これらの 成績、注意点などについてふれる。二次移植は、一般的にはその成績が 悪いと報告されているが、サイクロスポリンをはじめとする強力な免疫 抑制剂の使用により、一次移植とほぼ同じ成績がえられつつある。ただ し、二次移植ではOK T 3 やA L G などの、2 回使用不可能な製剤の使 用が制限されることがあり、拒絶反応治療に際して注意が必要となる。 前感作抗体陽性例に対する腎移植術は、最近はエリスロポイエチン製剤 の開発により透析中の輸血が激減したことにより少なくなっており、以 前ほど問題にはなっていない。われわれは、10 年前にこのような症例 にたいし血漿交換ののち腎移植を行ったが、これらの症例の長期予後に ついて報告する。非血縁者間の腎移植については賛否両論分かれるとこ ろではあるが、われわれの施設で行った 30 例について、その成績と問 題点について述べる。免疫学的ハイリスク患者にたいする腎移植は必ず しも容易ではないが、適切な処置により良好な成績が期待できるため、 ドナー不足の著しい本邦では積極的に取り組むべきものと考える。 